\title{
47. INTERCALIBRATION OF LEG 133 BIOSTRATIGRAPHIES
}

\author{
Stefan Gartner, ${ }^{2}$ Wuchang Wei, ${ }^{3}$ Dick Kroon, ${ }^{4}$ \\ and Christian Betzler ${ }^{5}$
}

\begin{abstract}
The biohorizons of calcareous nannofossil and planktonic foraminifers have been intercalibrated for Ocean Drilling Program (ODP) sites drilled during Leg 133 on the northeastern Australian margin. The absence of an independent chronology (e.g., magnetostratigraphy) limits the evaluation of biohorizons for assessing their relative positions within the framework of the best established chronologies. The nannofossil chronology was arbitrarily taken as the reference framework. The order of several late Neogene biohorizons is frequently reversed. Three possible explanations can be invoked: redeposition, inadequate sample spacing, and diachrony. In the absence of proper control on the first two of these explanations, the third possibility cannot be evaluated properly.
\end{abstract}

\section{INTRODUCTION}

ODP Leg 133 was devoted to exploration of the northeastern Australian continental margin, with a particular view to the history of parts of the Great Barrier Reef and adjacent carbonate platforms (Fig. 1; see also Davies, McKenzie, Palmer-Julson, et al., 1991). The general pattern of recovery is of late Neogene (late Miocene to Holocene) pelagic and hemipelagic sediments overlying shallowwater carbonates. Nearly all of the biostratigraphy for Leg 133 sediments was performed with calcareous nannofossils and planktonic foraminifers. The detailed data are given by Gartner et al. (this volume), Wei and Gartner (this volume), and Kroon (this volume). Where shallow-water carbonates were drilled, the sediments are generally devoid of planktonic fossils, or these fossils are extremely rare, generalized, and poorly preserved and are only marginally useful for dating. In these same sediments, the larger benthic foraminifers proved far more useful, and detailed data are given by Betzler and Chaproniere (this volume). Unfortunately, diagnostic plankton fossils and larger benthic foraminifers do not occur together naturally, and the chronology of the two groups cannot be integrated. When they do occur together, as in turbidites, both occurrences are suspect because of potential or actual redeposition, and a chronology built on such occurrences is not credible. Equally, the plankton biostratigraphy cannot be used to buttress benthic foraminifer biostratigraphy, and the converse is also true. Consequently, the chronologies constructed from the two groups stand alone.

However, it seems useful to intercalibrate the chronologies of the calcareous nannofossils and of the planktonic forminifers, because the two groups do occur naturally together, and both are exceptionally well developed in some of the sections that were recovered. Intercalibration may be useful in two ways. Any systematic deviation of the Leg 133 intercalibration and the reference calibration derived from, for instance, Berggren et al. (1985) may suggest that a real regional difference exists in the ranges of key species (We hesitate to use the word diachrony as that has become a shameful subterfuge that may

\footnotetext{
'McKenzie, J.A., Davies, P.J., Palmer-Julson, A., et al., 1993. Proc. ODP, Sci. Results, 133: College Station, TX (Ocean Drilling Program).

2 Department of Oceanography, Texas A\&M University, College Station, TX 77843. U.S.A.

${ }^{3}$ Scripps Institution of Oceanography, University of California at San Diego, La Jolla, CA 92093, U.S.A.

${ }^{4}$ Department of Geology and Geophysics, University of Edinburgh, West Mains Road, Edinburgh EH9 3JW, Scotland.

${ }^{5}$ Geologisch-Palaeontologisches Institut, Senckenberganlage 32-34, 6000 Frankfurt/Main 11. Federal Republic of Germany.
}

conceal some genuine problem as well as sloppy data), or possibly that the reference calibration needs to be refined further. A lack of correspondence that is not systematic might indicate that the two groups (calcareous nannofossils and planktonic foraminifers) were subjected to differential deposition (redeposition). The latter is an altogether real possibility given that much of the hemipelagic sediments recovered at several Leg 133 sites were deposited by contour currents and thus clearly experienced lateral transport.

One of the major disappointments of Leg 133 drilling was the failure to obtain a useful magnetic reversal stratigraphy for the sediments, in spite of the Herculean efforts of the participating magneticists. Consequently, the efficacy of the plankton biostratigraphy can be assessed only in terms of internal consistency; that is, in terms of whether biohorizons occur in the same relative position to each other. This assessment of internal consistency is given for nine sites. While such an assessment cannot yield actual corrections for numerical ages assigned to the biohorizons, it can provide powerful evidence that these biohorizons require further scrutiny, at least in regional biostratigraphic and chronostratigraphic contexts.

Figure 2 is a chronology of calcareous nannofossil biohorizons compiled from Berggren et al. (1985), with additions mainly from Baldauf et al. (1987). (For sources of other data, see also Gartner, 1992.) The age of each biohorizon is given in parentheses. The succession of nannofossil and planktonic foraminifer biohorizons is presented graphically for Sites 811 through 818 and for Site 823 in Figures 3 through 11. The ages assigned to the foraminiferal biohorizons were taken from Tables 1 and 2 of Kroon (this volume); these also were derived from Berggren et al. (1985). Numerical ages of planktonic foraminifer biohorizons are given in parentheses in Figures 3 through 11. The vertical bar in front of the arrow marking the highest or lowest occurrence of a planktonic foraminifer marker species indicates the distance between adjacent samples that were examined for that marker species. For the calcareous nannofossils, sample spacing was uniformly $150 \mathrm{~cm}$ and an arrow indicates the level, where the marker species was actually recorded. In assessing the biohorizons, the nannofossil chronology has been arbitrarily taken as the reference standard, although this is not meant to imply greater accuracy for that group than for planktonic foraminifers. Precision is almost certainly greater for calcareous nannofossils, simply because a larger number of samples was examined.

\section{SITE-BY-SITE RECORD}

At Site 811 (Fig. 3), the approximate correspondence of Globigerinodes fistulosus and $G$. obliquus confirms that a hiatus is near the 


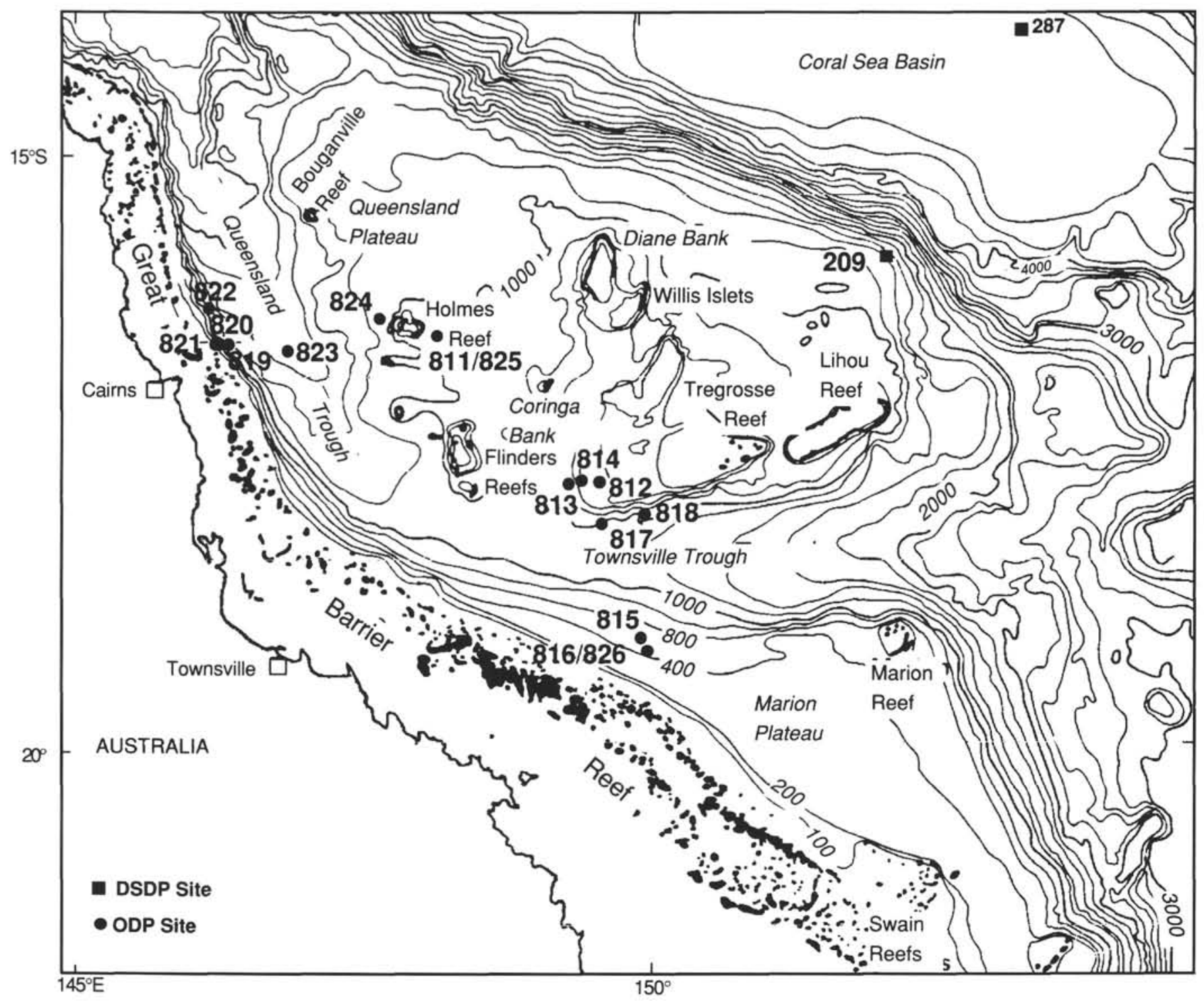

Figure 1. Location of sites cored during Leg 133.

Pliocene/Pleistocene boundary, as is also indicated by the correspondence of the highest occurrence of Calcidiscus macintyrei and Discoaster brouweri. The Globigerina nepenthes highest occurrences ( 3.9 m.y.) are too high relative to the highest occurrence of Sphenolithus abies (3.45 m.y.) and Reticulofenestra pseudoumbilica (3.51 m.y.), and the lowest occurrence of Globorotalia tumida tumida (5.2 m.y.) is too low relative to the highest occurrence of Discoaster quinqueramus (5.26 m.y.).

At Site 812 (Fig. 4), only three planktonic foraminifer biohorizons are clearly identifiable, the highest occurrences of Globigerinoides fistulosus (1.6 m.y.), G. obliquus (1.8 m.y.), and Globoquadrina altispira (2.9 m.y.), and their close spacing confirms that the uppermost Pliocene and lowermost Pleistocene sections are greatly attenuated, as is indicated also by the calcareous nannofossil biohorizons from the highest occurrence of Calcidiscus macintyrei (1.48 m.y.) down to the highest occurrence of Sphenolithus abies (3.45 m.y.). One benthic foraminifer biohorizon at approximately $275 \mathrm{mbsf}$, the occurrence of Nephrolepidina, having a $\mathrm{F}$ value of approximately 4 , indicates a middle Miocene age for this level; however, no plankton fossils were observed in this interval with which to intercalibrate other markers.

At Site 813 (Fig. 5), six planktonic foraminifer biohorizons can be recognized. The youngest two, the highest occurrences of Globig- erinoides fistulosus and G. obliquus -1.6 and 1.8 m.y., respectively, are between the top of the interval of dominance of small Gephyrocapsa and the highest occurrence of Calcidiscus macintyrei, which have ages of 0.93 and $1.48 \mathrm{~m} . \mathrm{y}$. , respectively. Clearly, redeposition of the planktonic foraminifers must be suspected for the mid-Pleistocene sediments at this site. The highest occurrences of Globoquadrina altispira (2.9 m.y.) and of Sphaeroidinellopsis sp. (3.0 m.y.) are at levels entirely compatible with nannofossil biohorizons, but the highest occurrence of Globigerina nepenthes (3.9 m.y.) is above the highest occurrence of Sphenolithus abies (3.45 m.y.), just as at Site 811 , and the lowest occurrence of Globorotalia tumida tumida (5.2 m.y.) is below the highest occurrence of Discoaster quinqueramus (5.26 m.y.). Clearly, the ages assigned to these last four biohorizons are suspect.

At Site 814 (Fig. 6), six planktonic foraminifer biohorizons are recognizable. The highest occurrences of Globigerinoides fistulosus (1.6 m.y) and $G$. obliquus (1.8 m.y.), agree well with calcareous nannofossil biohorizons, whereas the highest occurrences of Globoquadrina altispira (2.9 m.y.) and Sphaeroidinellopsis sp. (3.0 m.y.) are above the highest occurrence of Discoaster tamalis (2.6 m.y.). No obvious reason for this discrepancy can be seen. The two lowermost planktonic foraminifer biohorizons, the highest occurrence of Glo- 


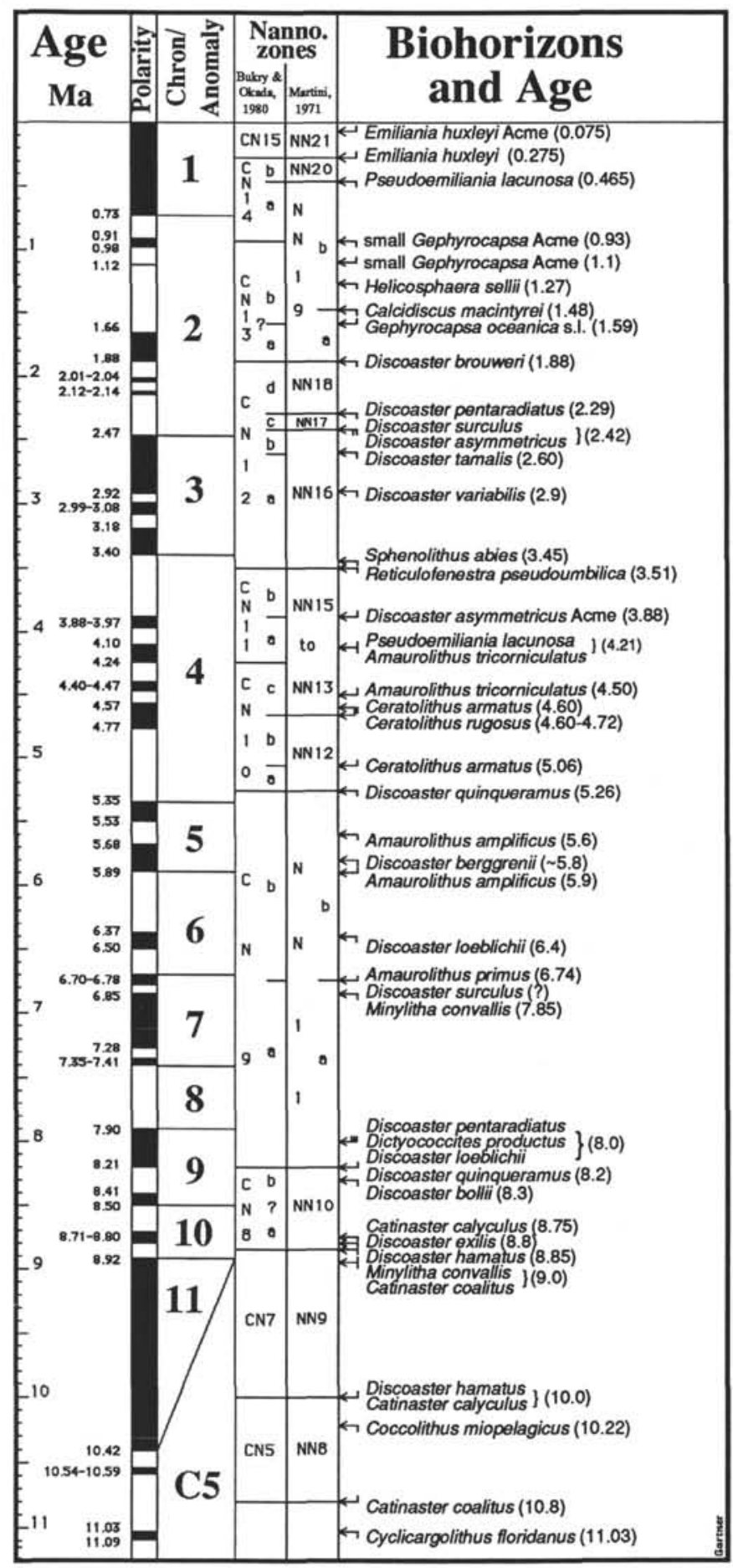

Figure 2. Calcareous nannofossil biohorizon chronology, compiled primarily from Berggren et al. (1985) and Baldauf et al. (1987).

bigerina nepenthes (3.9 m.y.) and lowest occurrence of Globorotalia tumida tumida (5.2 m.y.), are within an interval that, according to the succession of nannofossil biohorizons, contains a major hiatus within the lower Pliocene section. Two levels at this site have documented benthic foraminifer ages. Nephrolepidina howchini (F 4) occurs at about 103 mbsf, which is also the highest occurrence of (rare) Calcidiscus premacintyrei (11.7 m.y.; Gartner, 1992); N. howchini (F 4 to 5) occurs at about 207 mbsf; however, no datable nannofossils were recovered at this level. Both occurrences of this benthic species suggest a middle Miocene age.

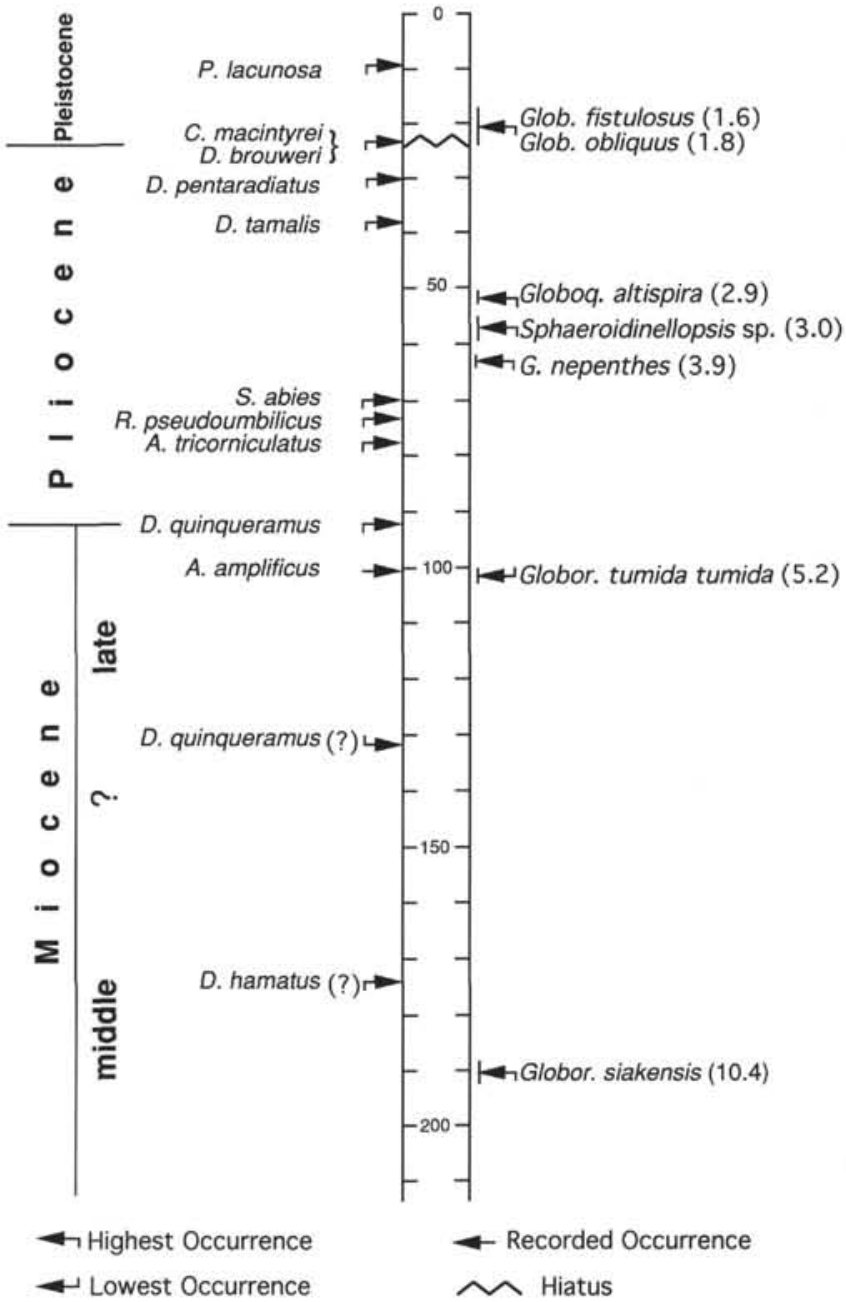

Figure 3. Calcareous nannofossil and planktonic foraminifer biohorizons identified at Site 811 plotted vs. depth. Age assignments are arbitrarily based on calcareous nannofossils. Numerical ages for the calcareous nannofossils should be taken from Figure 1; numerical ages of planktonic foraminifers are given in parentheses.

Site 815 (Fig. 7) yielded four significant planktonic foraminifer biohorizons. The highest occurrence of Globigerinoides fistulosus (1.6 m.y.) is higher than predicted from the succession of calcareous nannofossil biohorizons; it clearly occurs above the highest occurrence of Helicosphaera sellii (1.27 m.y.) and the highest occurrence of Calcidiscus macintyrei (1.48 m.y.). However, the highest occurrence of Globigerinoides obliquus (1.8 m.y.) agrees closely with the nannofossil biohorizons. The highest occurrences of Globoquadrina altispira (2.9 m.y.) and Sphaeroidinellopsis sp. (3.0 m.y.) are within the interval predicted from nannofossil biohorizons. Unfortunately, their accuracy cannot be gaged because of the great change in sedimentation rate in the upper Pliocene section at this site. The highest occurrence of Globigerina nepenthes (3.9 m.y.) is below the lowest occurrence of Pseudoemiliania lacunosa and the highest occurrence of Amaurolithus tricorniculatus (both 4.21 m.y.), and the ages of these three biohorizons may have to be examined further. Finally, the lowest occurrence of Globorotalia tumida tumida (5.2 m.y) again is below the highest occurrence of Discoaster quinqueramus (5.26 m.y.), and these clearly require revision.

Four planktonic foraminifer biohorizons can be recognized at Site 816 (Fig. 8). Globigerinoides fistulosus (1.6 m.y.) appears too high relative to Calcidiscus macintyrei (1.48 m.y.), but the highest occur- 


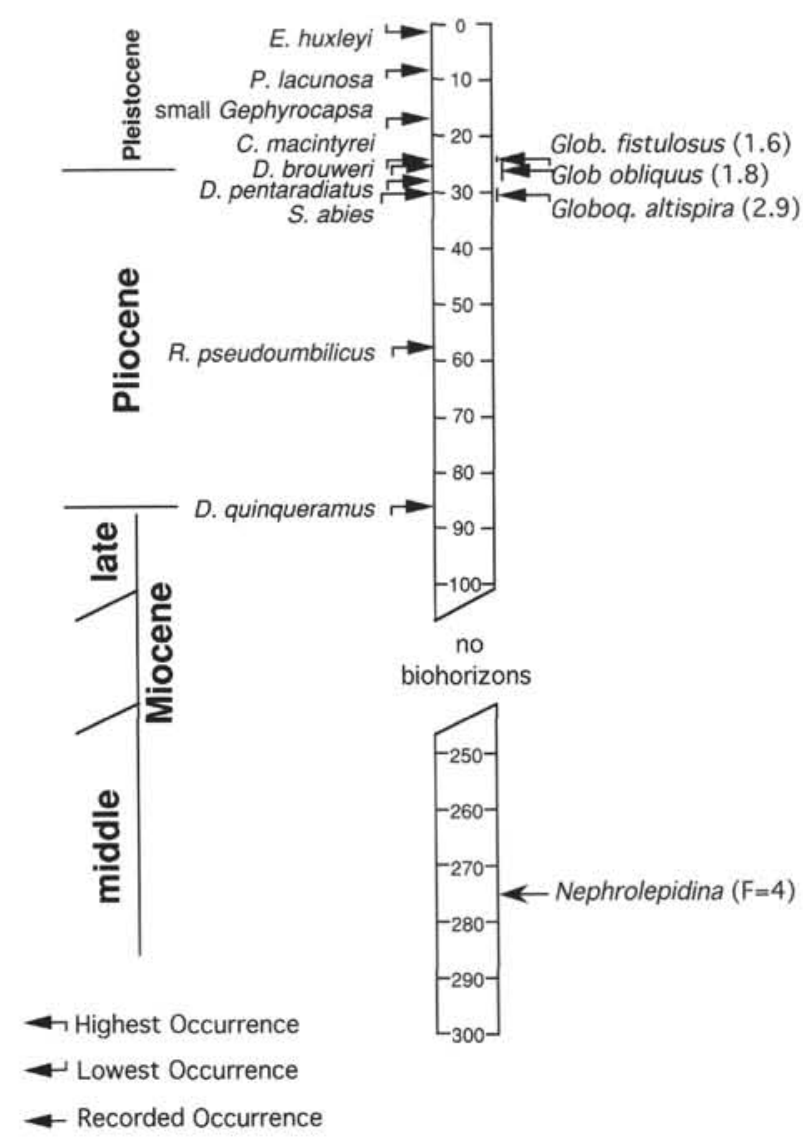

Figure 4. Calcareous nannofossil and planktonic foraminifer biohorizons identified at Site 812 plotted vs. depth. Age assignments are arbitrarily based on calcareous nannofossils. Numerical ages for the calcareous nannofossils should be taken from Figure 1; numerical ages of planktonic foraminifers are given in parentheses.

rence of G. obliquus (1.8 m.y.) is compatible with other nearby datums. The highest occurrences of Globoquadrina altispira (2.9 m.y.) and Sphaeroidinellopsis sp. (3.0 m.y.) also are compatible with nearby nannofossil biohorizons, as the highest occurrence of Discoaster tamalis (2.60 m.y.) is above them and the highest occurrence of Sphenolithus abies ( 3.45 m.y.) is below them.

Site 817 (Fig. 9) yielded seven planktonic foraminifer biohorizons. The highest occurrence of Globigerinoides fistulosus (1.6 m.y.) may be too high, but is within the interval predicted from calcareous nannofossils. The highest occurrence of $G$. obliquus $(1.8 \mathrm{~m} . \mathrm{y}$.) is approximately where expected, although the uppermost Pliocene and lowermost Pleistocene sections are missing. The highest occurrences of Globoquadrina altispira (2.9 m.y.) and Sphaeroidinellopsis sp. ( 3.0 m.y.) also are within the predicted interval, bracketed by the highest occurrences of Discoaster tamalis (2.6 m.y.) and Sphenolithus abies (3.45 m.y.). The highest occurrence of Globigerina nepenthes ( 3.9 m.y.) is at or just above the highest occurrence of Sphenolithus abies (3.45 m.y.), as at several other nearby sites, and the lowest occurrence of Globorotalia tumida tumida (5.2 m.y.) is at about 185 mbsf, below the highest occurrence of Discoaster quinqueramus (5.26 m.y.). One additional foraminiferal biohorizon, the Globorotalia siakensis highest occurrence (10.4 m.y.) occurs at or just below the lowest occurrence of Discoaster quinqueramus (8.2 m.y.), but about $20 \mathrm{~m}$ above the highest occurrence of Coccolithus miopelagicus (10.22 m.y.); however, changes in dominant sedimentation style probably account for the lack of correspondence of biohorizons at this level.

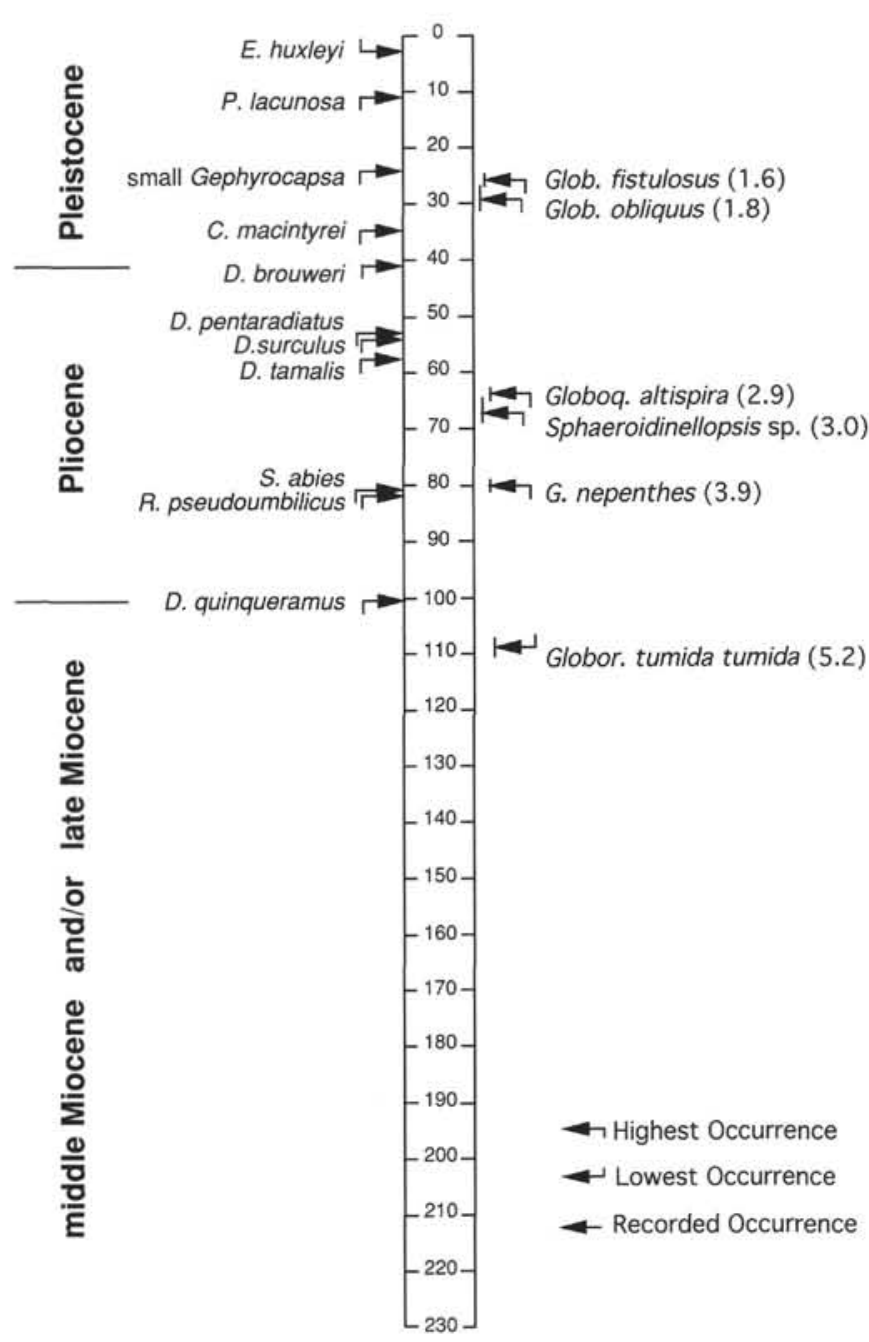

Figure 5. Calcareous nannofossil and planktonic foraminifer biohorizons identified at Site 813 plotted vs. depth. Age assignments are arbitrarily based on calcareous nannofossils. Numerical ages for the calcareous nannofossils should be taken from Figure 1; numerical ages of planktonic foraminifers are given in parentheses.

Site 818 (Fig. 10) yielded six planktonic foraminifer biohorizons. The highest occurrences of Globigerinoides fistulosus (1.6 m.y.) and G. obliquus $(1.8 \mathrm{~m} . \mathrm{y}$ ) at about $83 \mathrm{mbsf}$ coincide. At this level, calcareous nannofossils indicate a hiatus that includes the Pliocene/ Pleistocene boundary. The highest occurrences of Globoquadrina altispira (2.9 m.y.) and Sphaeroidinellopsis sp. (3.0 m.y.) are in correct order and in the correct position relative to Discoaster tamalis (2.6 m.y.) and Sphenolithus abies (3.45 m.y.); however, the highly variable sedimentation rate at this site precludes judging the accuracy of all of the biohorizons. The highest occurrence of Globigerina nepenthes (3.9 m.y.) is below the highest occurrence of Reticulofenestra pseudoumbilica (3.51 m.y.), as predicted. The lowest occurrence of Globorotalia tumida tumida (5.2 m.y.), at about 298 mbsf, probably should be disregarded because it is at the bottom of the cored section and is not supported by any other biohorizons.

Site 823 (Fig. 11) yielded seven planktonic foraminifer biohorizons. The highest occurrence of Globigerinoides fistulosus (1.6 m.y.) at approximately $153 \mathrm{mbsf}$ is just below the highest occurrence of Calcidiscus macintyrei (1.48 m.y.) and above the highest occurrence of Discoaster brouweri (1.88 m.y.), although the highest occurrence of Globigerinoides obliquus (1.8 m.y.) is considerably farther down, at about 204 mbsf and closer to the highest occurrence of Discoaster 


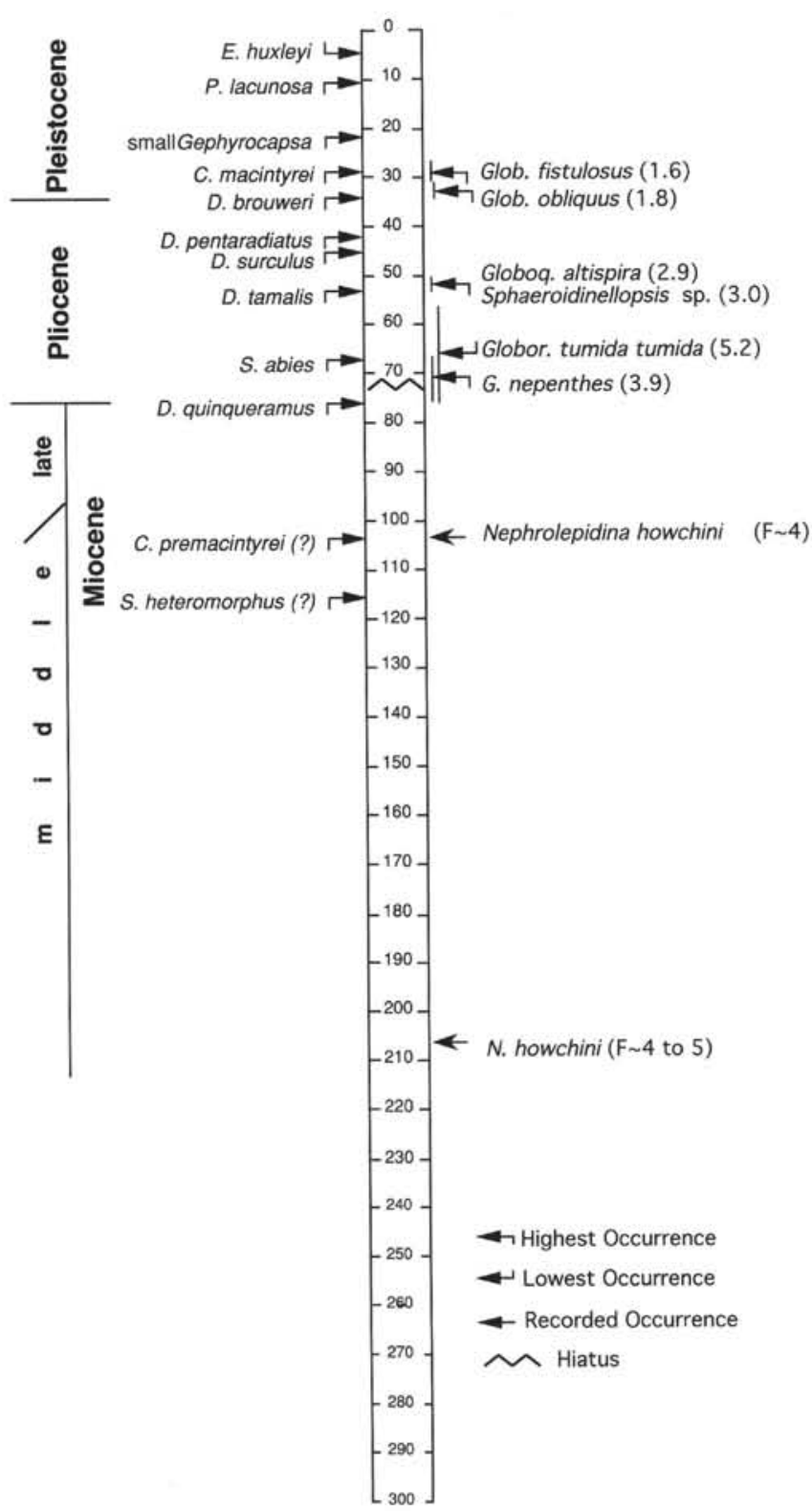

Figure 6. Calcareous nannofossil and planktonic foraminifer biohorizons identified at Site 814, plotted vs. depth. Age assignments are arbitrarily based on calcareous nannofossils. Numerical ages for the calcareous nannofossils should be taken from Figure 1; numerical ages of planktonic foraminifers are given in parentheses.

pentaradiatus ( 2.29 m.y.). The highest occurrences of Globoquadrina altispira (2.9 m.y.) and Sphaeroidinellopsis sp. (3.0 m.y.) are in correct order and correct position relative to Discoaster tamalis (2.6 m.y.) and Reticulofenestra pseudoumbilica (3.51 m.y.). The highest occurrence of Globigerina nepenthes (3.9 m.y.) is also correctly positioned between the bottom of the Discoaster asymmetricus Acme (3.88 m.y.) and the highest occurrence of Amaurolithus tricorniculatus (4.21 m.y.). Globorotalia tumida tumida (5.2 m.y.) is (by now) predictably below the highest occurrence of Discoaster quinqueramus (5.26 m.y.) at approximately $675 \mathrm{mbsf}$. The lowest planktonic foraminifer biohorizon at this site is the highest occurrence of Globorotalia siakensis (10.4 m.y.) at approximately $1008 \mathrm{mbsf}$, below the highest occurrence of Catinaster coalitus $(9.0$ m.y.). The accuracy of these two biohorizons relative to each other cannot be judged even qualitatively because coring did not extend significantly below the former datum.

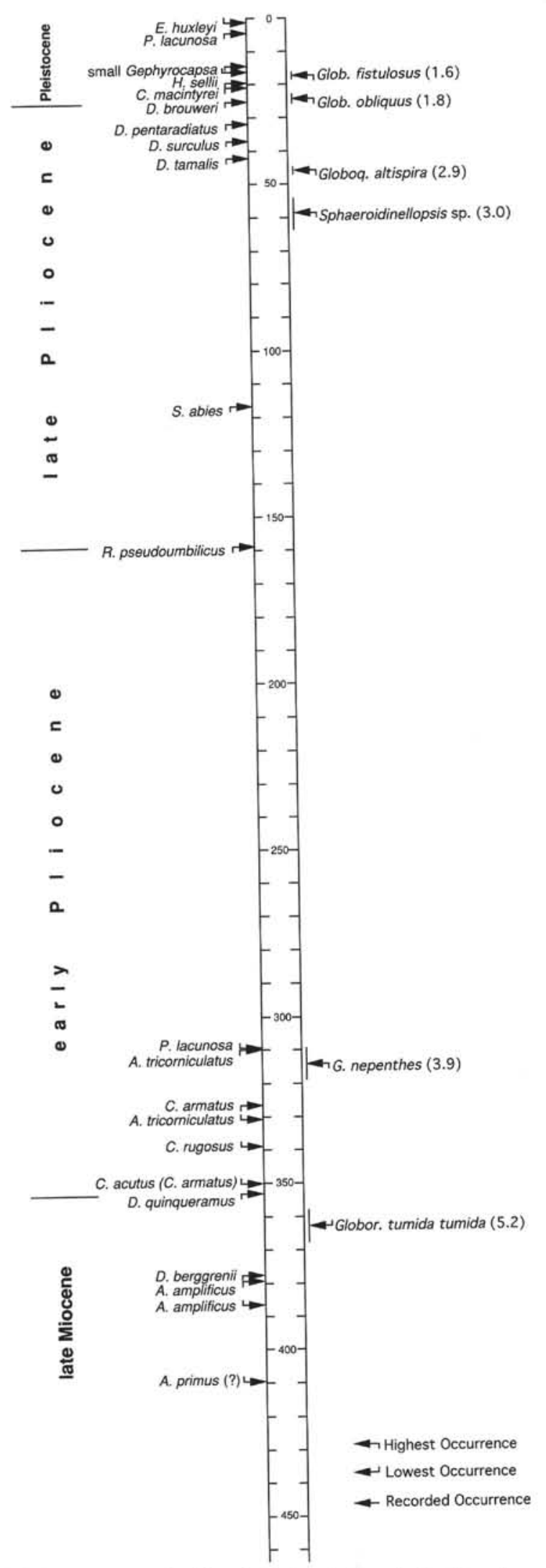

Figure 7. Calcareous nannofossil and planktonic foraminifer biohorizons identified at Site 815, plotted vs. depth. Age assignments are arbitrarily based on calcareous nannofossils. Numerical ages for the calcareous nannofossils should be taken from Figure 1; numerical ages of planktonic foraminifers are given in parentheses. 


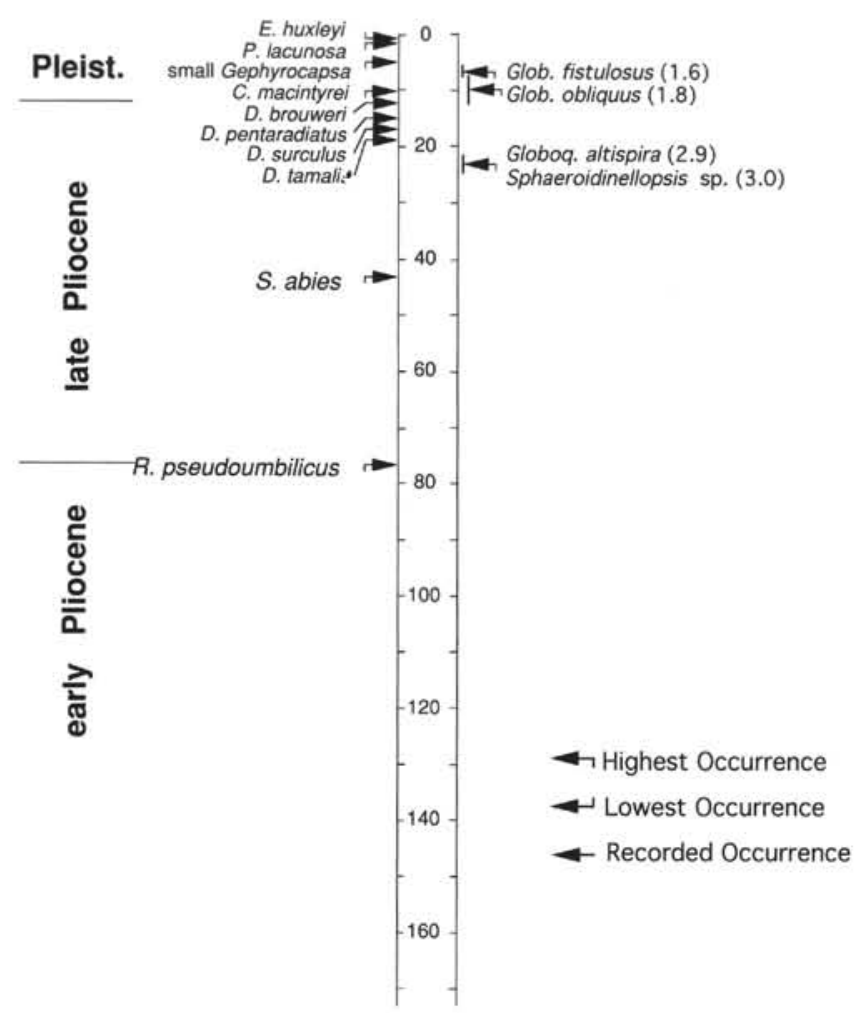

Figure 8. Calcareous nannofossil and planktonic foraminifer biohorizons identified at Site 816 plotted vs. depth. Age assignments are arbitrarily based on calcareous nannofossils. Numerical ages for the calcareous nannofossils should be taken from Figure 1; numerical ages of planktonic foraminifers are given in parentheses.

\section{SUMMARY AND DISCUSSION OF SOME LATE NEOGENE BIOHORIZON AGES}

The youngest planktonic foraminifer biohorizon consistently identified is the highest occurrence of Globigerinoides fistulosus, with a calibrated age of $1.6 \mathrm{~m}$.y. Its nearest consistently identified nannofossil counterpart is Calcidiscus macintyrei, which has a calibrated age of $1.48 \mathrm{~m} . \mathrm{y}$. The highest occurrence of Globigerinoides fistulosus is above the highest occurrence of Calcidiscus macintyrei at Sites 813, 815 , and 816 . The order is reversed at Sites 817,818 , and 823. At Sites 811,812 , and 814 , these two datums coincide within the limit of sample spacing.

The highest occurrence of Globigerinoides obliquús has been calibrated to an age of $1.8 \mathrm{~m}$.y.; this datum has been compared with the highest occurrence of Discoaster brouweri, which has a calibrated age of $1.88 \mathrm{~m} . \mathrm{y}$. These two biohorizons are in correct relative position or within the limit of sample spacing at all sites, except Sites 813 and 823 . At Site 813, Globigerinoides obliquus occurs to well above the highest occurrence of Calcidiscus macintyrei, whereas at Site 823, this same datum is well below the highest occurrence of Discoaster brouweri.

The highest occurrences of Globoquadrina altispira and of Sphaeroidinellopsis sp. have been calibrated to 2.9 and 3.0 m.y., respectively, and the nearest nannofossil biohorizons are Discoaster tamalis above and Sphenolithus abies below, which have ages of 2.6 and 3.48 m.y., respectively. The relative positions of these four biohorizons are correct at all sites, except for Site 814, where these and other biohorizons seem to be compromised by hiatuses.

The Globigerina nepenthes highest occurrence has a nominal age of 3.9 m.y.; it should correspond closely to the base of the Discoaster asymmetricus Acme (3.88 m.y.) and be positioned about midway between the highest occurrence of Reticulofenestra pseudoumbilica

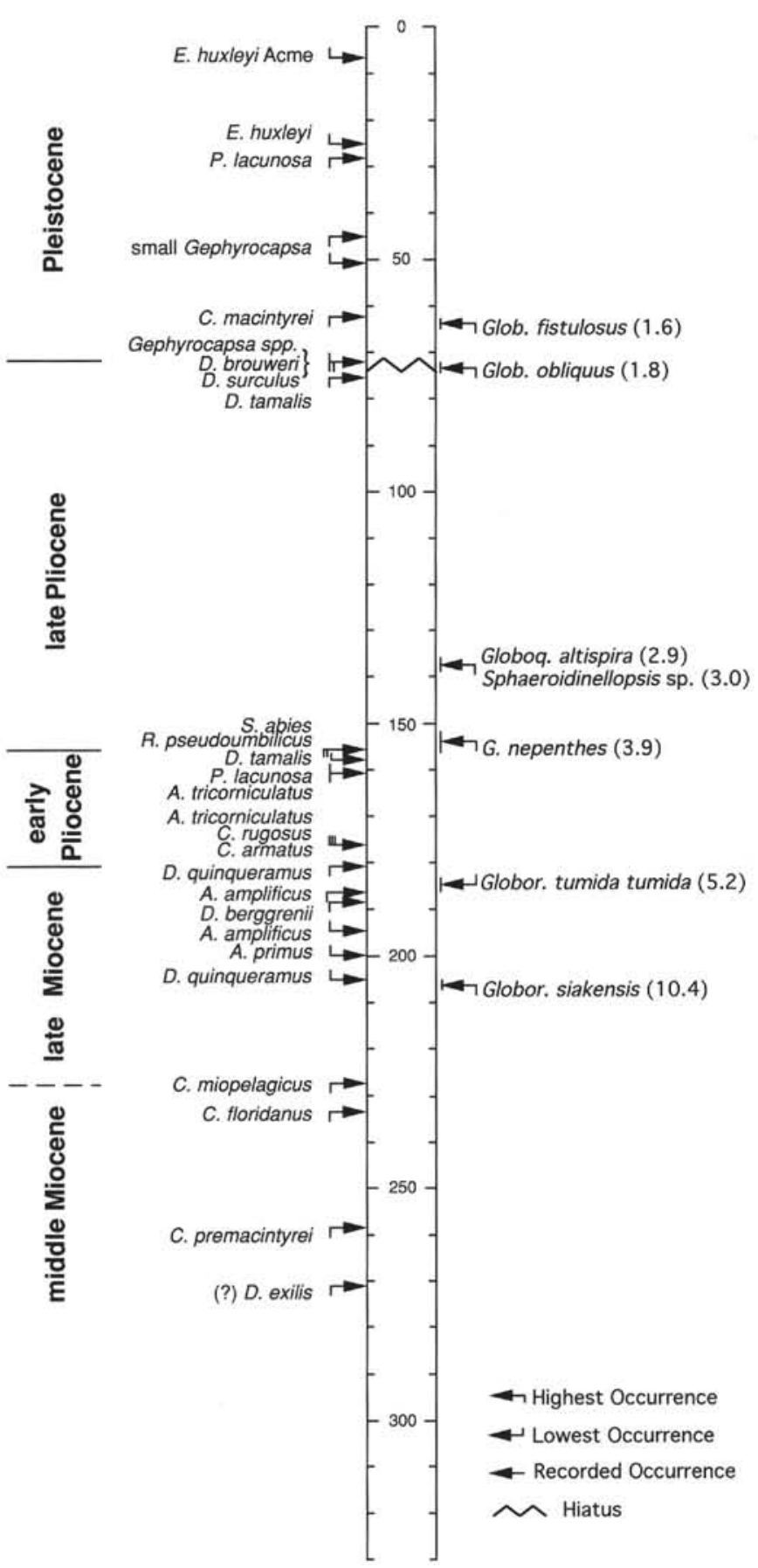

Figure 9. Calcareous nannofossil and planktonic foraminifer biohorizons identified at Site 817, plotted vs. depth. Age assignments are arbitrarily based on calcareous nannofossils. Numerical ages for the calcareous nannofossils should be taken from Figure 1; numerical ages of planktonic foraminifers are given in parentheses.

(3.51 m.y) and Amaurolithus tricorniculatus (4.21 m.y.). At Site 811, the Globigerina nepenthes highest occurrence is above the Reticulofenestra pseudoumbilica highest occurrence; at Site 818 the order is reversed; and at Sites 813,815 , and 817 the two correspond within the limit of sample spacing. At Site 823 the $G$. nepenthes highest occurrence is even farther down, nearly $60 \mathrm{~m}$ below the lower limit of the Discoaster asymmetricus Acme, and at Site 814 this datum is compromised by hiatuses over the critical interval. The $G$. nepenthes highest occurrence datum was not identified at Sites 812 and 816. 
The lowest occurrence of Globorotalia tumida tumida has an estimated age of $5.2 \mathrm{~m} . \mathrm{y}$. This should correspond closely to the level just above the highest occurrence of Discoaster quinqueramus (5.26 m.y.). Instead, the former occurs below the latter, as at Sites 811,813 , 815,817 , and 823 . One or both datums were not recorded at Sites 812 , 816 , and 818 , and Site 814 has been compromised by hiatuses. The ages of these last two datums obviously are in need of revision. Clearly, Globorotalia tumida tumida appeared in the Coral Sea region prior to the extinction of Discoaster quinqueramus, although not much earlier.

\section{REFERENCES}

Baldauf, J.G., Thomas, E., Clement, B., Takayama, T., Weaver, P.P.E., Backman, J., Jenkins, G., Mudie, P.J., and Westberg-Smith, M.J., 1987. Magnetostratigraphic and biostratigraphic synthesis, Deep Sea Drilling Project Leg 94. In Ruddiman, W.F., Kidd, R.B., et al., Init. Repts. DSDP, 94 (Pt. 2): Washington (U.S. Govt. Printing Office), 1159-1205.

Berggren, W.A., Kent, D.V., and Van Couvering, J.A., 1985. The Neogene: Part 2. Neogene geochronology and chronostratigraphy. In Snelling, N.J. (Ed.), The Chronology of the Geological Record. Geol. Soc. London Mem., 10:211-260.

Davies, P.J., McKenzie, J.A., Palmer-Julson, A., et al., 1991. Proc. ODP, Init. Repts., 133: College Station, TX (Ocean Drilling Program).

Gartner, S., 1992. Miocene nannofossil chronology in the North Atlantic, DSDP Site 608. Mar. Micropaleontol., 18:307-331.

"Abbreviations for names of organizations and publication titles in ODP reference lists follow the style given in Chemical Abstracts Service Source Index (published by American Chemical Society).

Date of initial receipt: 3 September 1992

Date of acceptance: 10 March 1993

Ms 133SR-281

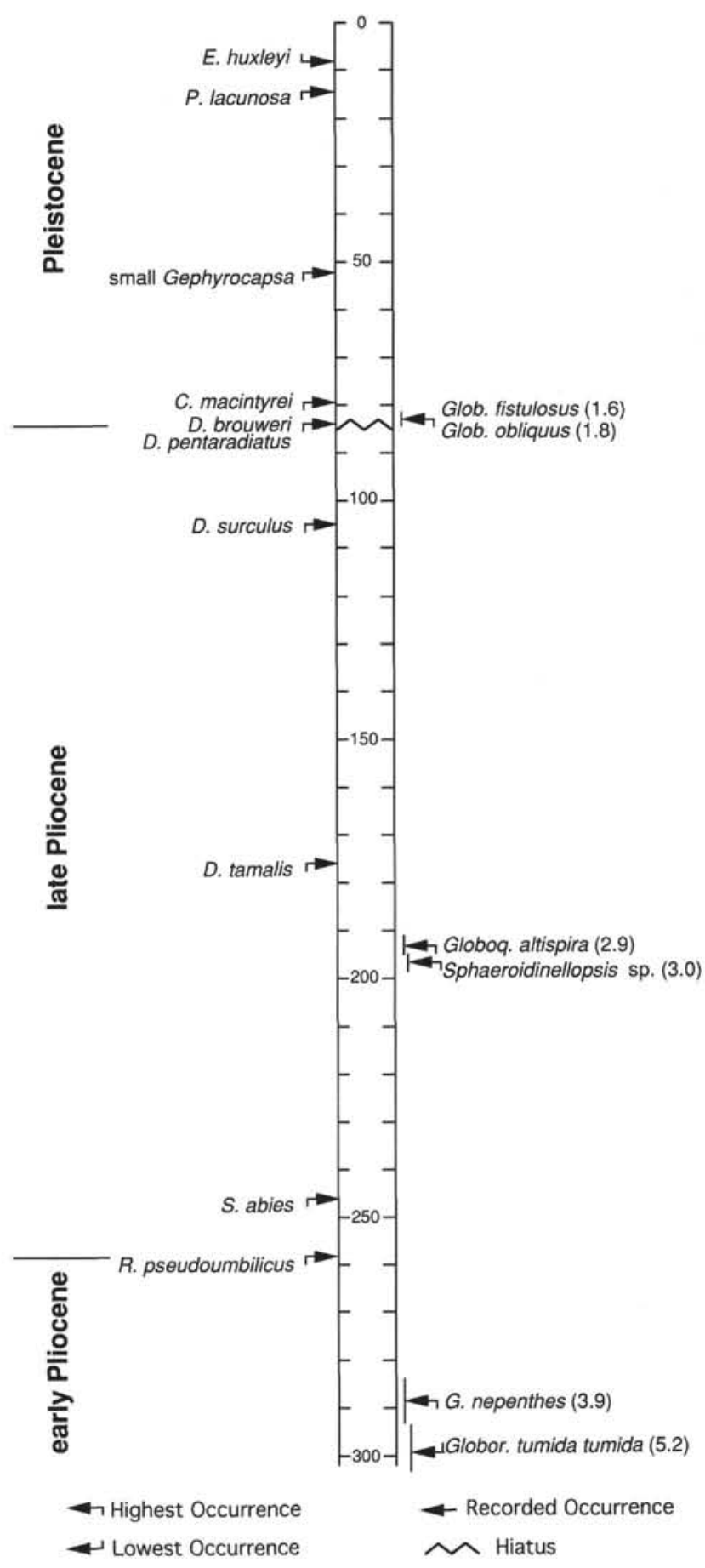

Figure 10. Calcareous nannofossil and planktonic foraminifer biohorizons identified at Site 818 , plotted vs. depth. Age assignments are arbitrarily based on calcareous nannofossils. Numerical ages for the calcareous nannofossils should be taken from Figure 1; numerical ages of planktonic foraminifers are given in parentheses. 

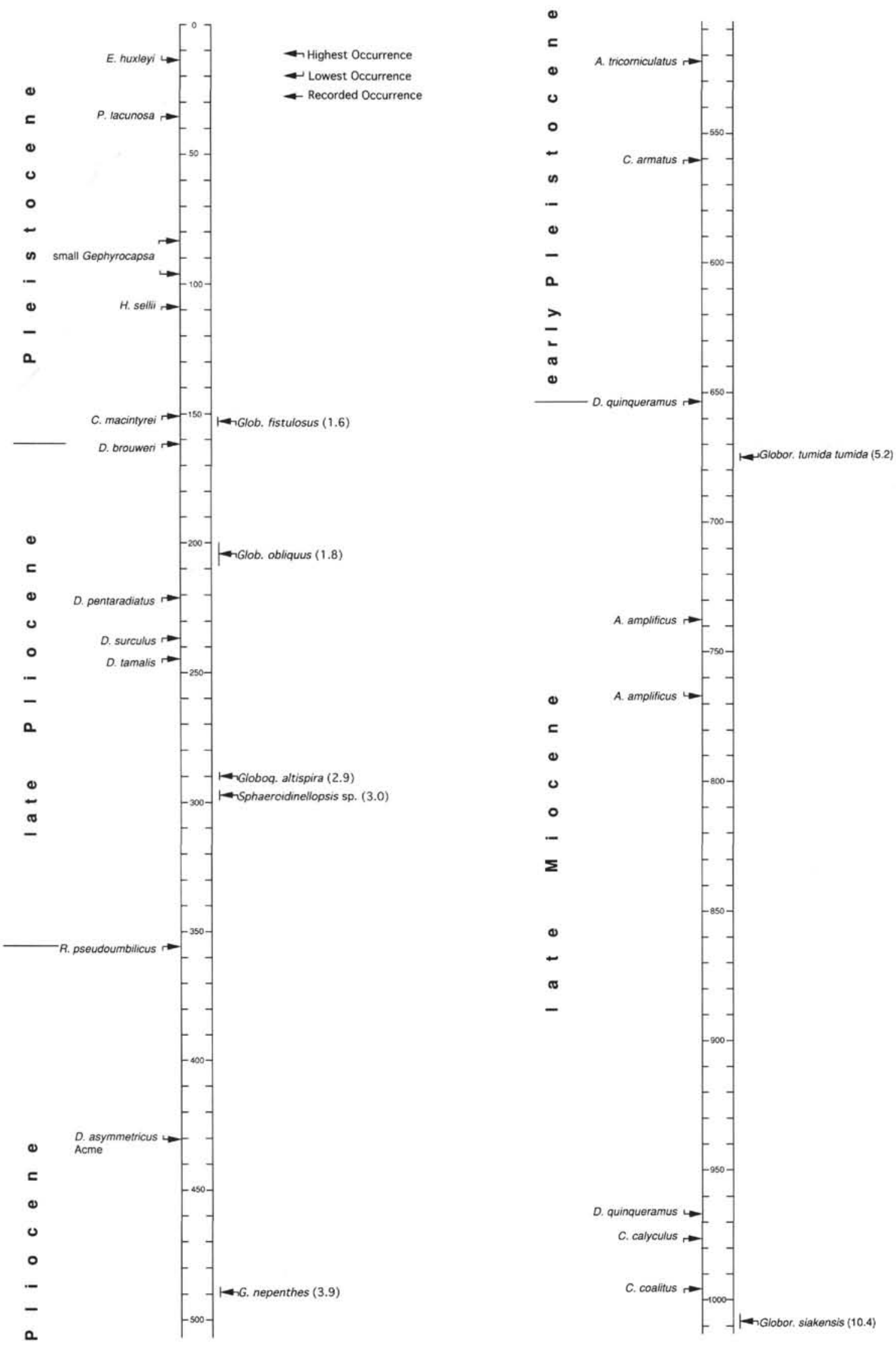

Figure 11. Calcareous nannofossil and planktonic foraminifer biohorizons identified at Site 823, plotted vs. depth. Age assignments are arbitrarily based on calcareous nannofossils. Numerical ages for the calcareous nannofossils should be taken from Figure 1; numerical ages of planktonic foraminifers are given in parentheses. 